\title{
Interactive comment on "Microphysical
} investigation of the seeder and feeder region of an Alpine mixed-phase cloud" by Fabiola Ramelli et

\section{al.}

\section{Fabiola Ramelli et al.}

fabiola.ramelli@env.ethz.ch

Received and published: 15 February 2021

The comment was uploaded in the form of a supplement:

https://acp.copernicus.org/preprints/acp-2020-772/acp-2020-772-AC1-supplement.pdf

Interactive comment on Atmos. Chem. Phys. Discuss., https://doi.org/10.5194/acp-2020-772, 2020. 